\title{
The role of myo-inositol in multiple sclerosis
}

\author{
GB YOUNG,${ }^{*}$ WJ HADER, $†$ M HISCOCK,$\dagger$ KG WARREN, D LOGAN $\S$ \\ From the University of Western Ontario, London, Ontario, ${ }^{*}$ The University of Saskatchewan, Saskatoon, \\ Saskatchewan, $\dagger$ The University of Alberta, Edmonton, Alberta, $\ddagger$ and York University, Downsview, Ontario, $\S$ \\ Canada
}

SUMMARY Myo-inositol was given orally to nine multiple sclerosis patients and nine healthy control subjects. Pattern reversal evoked potential testing was used to assess its effect. The principal positive wave increased in amplitude, duration and area in a dose-dependent manner in the multiple sclerosis group compared with controls. Cerebrospinal fluid concentrations of myo-inositol in multiple sclerosis and controls were similar. The significance of these observations is discussed in relation to recent discoveries in inositol phospholipid function.

Myo-inositol and inositol phospholipids are components of plasma membrane and myelin. ${ }^{1}$ They have achieved recent recognition for roles in metabolic regulation of nervous tissue ${ }^{2}$ and in receptor physiology. ${ }^{3-9}$ In a preliminary report $\mathrm{Holm}^{10}$ showed that $27 \%$ of patients with multiple sclerosis appeared to metabolise myo-inositol abnormally: when myo-inositol was added to their sera a large change in redox potential occurred compared with controls. Altered myo-inositol metabolism in diabetes mellitus has also been proposed as a cause of altered nerve conduction. ${ }^{11}$ We decided to pursue a possible role of myo-inositol in multiple sclerosis by: (1) examining the electrophysiological effects of orallyadministered myo-inositol in multiple sclerosis patients and control subjects and (2) measuring myoinositol in the cerebrospinal fluid (CSF) in multiple sclerosis and control patients.

\section{Methods}

The experiment was divided into two parts: (A) measurement of the effects of myo-inositol on pattern reversal evoked potentials in multiple sclerosis patients and controls and (B) determination of myo-inositol concentrations in the CSF in multiple sclerosis patients and controls.

(A) Myo-inositol and pattern reversal evoked potentials Nine patients with clinically definite multiple sclerosis (using Schumacher criteria ${ }^{12}$ ) were matched within 3 years for age and for sex with nine healthy volunteers. Patients ranged in age from 22-44 years. Six were female and three were male. Subjects in both groups had visual acuities of $20 / 30$ or

Address for reprint requests: Dr G Bryan Young, Victoria Hospital. South Street Campus, London, Ontario, Canada, N6A 4G5.

Received 30 October 1984 and in revised form 22 March 1985. Accepted 28 May 1985 better. We tested all subjects in an identical manner with the same ambient lighting and at approximately the same time of day for each subject using a Nicolet CA 1000 Clinical Averager System. The reversing black and white checker board pattern was one metre from the subject's eye, with each square subtending 27 minutes of arc. Luminance was $700 \mathrm{~cd} / \mathrm{m}^{2}$ for white and $0.7 \mathrm{~cd} / \mathrm{m}^{2}$ for dark squares. The pattern reversed at 1.88 times/second. Each eye was tested separately twice at each testing session, with 100 repetitions per determination. Bandpass filter settings were $5-100 \mathrm{~Hz}$. Scalp disk electrodes were used with $\mathrm{O}_{z}-\mathrm{C}_{z}$ derivation; impedances were $2-4 \mathrm{k}$ ohms. Printout was on an $\mathrm{X}-\mathrm{Y}$ plotter.

The major positive wave was clearly identified in each case. $\mathrm{N}_{1}, \mathrm{P}_{2}$ and $\mathrm{N}_{2}$ peaks were identified (fig 1). Latency was from the time from the stimulus trigger to the peak of the $P_{2}$ wave. Amplitude was defined as the voltage difference between the $N_{1}$ and $P_{2}$ peaks. Duration was the $N_{2}-N_{1}$ peak to peak time difference. When values differed slightly in the 2 tests per determination, the values were averaged. The area "under the curve" was approximated by joining $\mathrm{N}_{1}, \mathrm{~N}_{2}$ and $\mathrm{P}_{2}$ points with straight lines and determining the area of the triangle so formed.

Each subject had four testing sessions. In Trial 1 the subject took no medication. Trial 2 testing was performed after $500 \mathrm{mg}$ of myo-inositol was taken daily by mouth for 2 weeks. Trial 3 was performed after $1000 \mathrm{mg}$ daily for two weeks and Trial 4 after no medication for two weeks. Myoinositol was given in gelatin capsules containing $500 \mathrm{mg}$. A single dose was given each morning; pattern reversal evoked potential testing was performed between 3-6 hours after the last dose.

Statistical treatment of Part A utilised two sequential analyses of variance (ANOVAs) which were performed on each of the four dependent variables, that is latency, amplitude, duration and area subtended by the $\mathrm{N}_{1} \mathrm{P}_{2} \mathrm{~N}_{2}$ complex. In each case the first analysis was a $2 \times 2 \times 2$ ANOVA in which the respective independent variables were group (multiple sclerosis versus control), eye (left versus right) and Trial (1 versus 4 ). The purpose of this preliminary analysis was to detect any significant change between the initial medication 


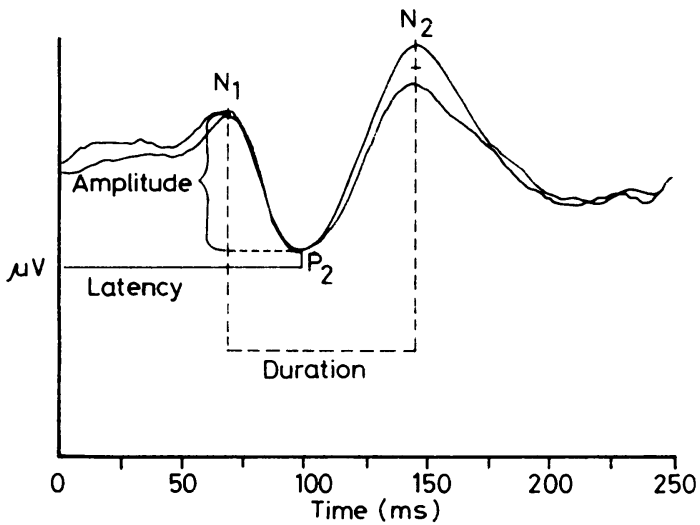

Fig 1 Two superimposed PREP responses are plotted with amplitude, latency and duration determination.
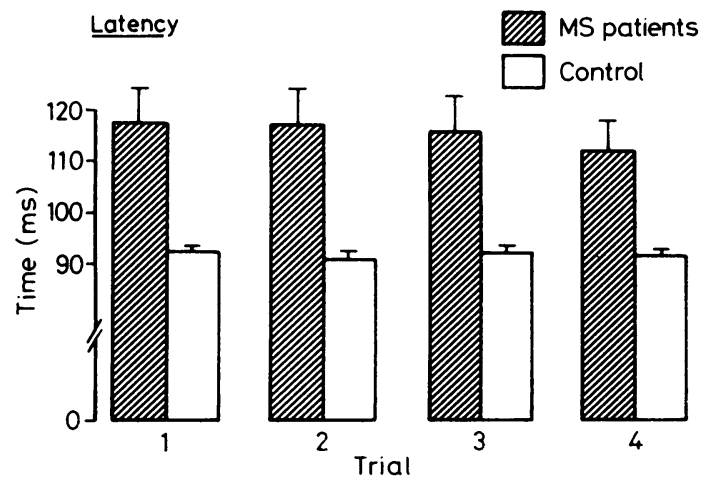

Fig 2 Mean latency values for multiple sclerosis patients and controls for the four Trials are shown. Vertical lines represent standard errors of measurement. The two groups differed significantly from each other but no effect from myo-inositol was found.

Table 1 Multiple sclerosis patients

\begin{tabular}{|c|c|c|c|c|c|c|c|c|c|}
\hline \multirow[t]{2}{*}{ Patientiage $(y r)$} & \multirow[t]{2}{*}{ Trial } & \multicolumn{2}{|c|}{ Latency ( $\mathrm{ms}$ ) } & \multicolumn{2}{|c|}{ Amplitude $(\mu V)$} & \multicolumn{2}{|c|}{ Duration (ms) } & \multicolumn{2}{|c|}{ Area $(\mu V-m s)$} \\
\hline & & Lefi eye & Right eye & Lefi eye & Right eye & Left eye & Right eye & Left eye & Right eve \\
\hline A 33 & $\begin{array}{l}1 \\
2 \\
3 \\
4\end{array}$ & $\begin{array}{l}134.00 \\
134.00 \\
137.00 \\
137.50\end{array}$ & $\begin{array}{l}135.00 \\
133.00 \\
132.00 \\
134.00\end{array}$ & $\begin{array}{l}2.70 \\
7.00 \\
7.95 \\
5.95\end{array}$ & $\begin{array}{l}4.05 \\
4.80 \\
6.50 \\
5.00\end{array}$ & $\begin{array}{l}57 \cdot 00 \\
61 \cdot 50 \\
61 \cdot 00 \\
64 \cdot 00\end{array}$ & $\begin{array}{l}66 \cdot 50 \\
58 \cdot 00 \\
63 \cdot 00 \\
64 \cdot 00\end{array}$ & $\begin{array}{r}76 \cdot 95 \\
215 \cdot 25 \\
242 \cdot 48 \\
190 \cdot 40\end{array}$ & $\begin{array}{l}159.60 \\
139 \cdot 20 \\
204.75 \\
160.00\end{array}$ \\
\hline В 44 & $\begin{array}{l}1 \\
2 \\
3 \\
4\end{array}$ & $\begin{array}{l}92.00 \\
92.00 \\
94.00 \\
91.00\end{array}$ & $\begin{array}{l}94.00 \\
94.00 \\
92.50 \\
94.00\end{array}$ & $\begin{array}{l}7 \cdot 30 \\
6.50 \\
6 \cdot 85 \\
5.95\end{array}$ & $\begin{array}{l}8.00 \\
5 \cdot 60 \\
6 \cdot 35 \\
5 \cdot 85\end{array}$ & $\begin{array}{l}50 \cdot 50 \\
54 \cdot 00 \\
48 \cdot 00 \\
49 \cdot 00\end{array}$ & $\begin{array}{l}48 \cdot 00 \\
51 \cdot 00 \\
43 \cdot 00 \\
49 \cdot 50\end{array}$ & $\begin{array}{l}184 \cdot 33 \\
175 \cdot 50 \\
164 \cdot 40 \\
145 \cdot 78\end{array}$ & $\begin{array}{l}192.00 \\
142.80 \\
136.53 \\
144.79\end{array}$ \\
\hline C 31 & $\begin{array}{l}1 \\
2 \\
3 \\
4\end{array}$ & $\begin{array}{l}102.00 \\
101.50 \\
101.00 \\
103.50\end{array}$ & $\begin{array}{l}128.00 \\
121.00 \\
121.00 \\
124.00\end{array}$ & $\begin{array}{l}3.75 \\
2.90 \\
4.20 \\
2.96\end{array}$ & $\begin{array}{l}1.50 \\
3.11 \\
3.60 \\
1.96\end{array}$ & $\begin{array}{l}55 \cdot 50 \\
57.00 \\
55.00 \\
46.50\end{array}$ & $\begin{array}{l}39 \cdot 50 \\
58 \cdot 00 \\
59 \cdot 00 \\
50 \cdot 00\end{array}$ & $\begin{array}{r}104.07 \\
82.65 \\
115.50 \\
68.82\end{array}$ & $\begin{array}{r}29 \cdot 63 \\
90 \cdot 19 \\
106.20 \\
49 \cdot 00\end{array}$ \\
\hline D 36 & $\begin{array}{l}1 \\
2 \\
3 \\
4\end{array}$ & $\begin{array}{r}101.50 \\
103.00 \\
95.00 \\
101.50\end{array}$ & $\begin{array}{r}98.50 \\
101.00 \\
100.00 \\
99.50\end{array}$ & $\begin{array}{l}4 \cdot 25 \\
5 \cdot 31 \\
4 \cdot 00 \\
4 \cdot 70\end{array}$ & $\begin{array}{l}5.75 \\
5.21 \\
5.40 \\
4.45\end{array}$ & $\begin{array}{l}44 \cdot 50 \\
52 \cdot 00 \\
42 \cdot 00 \\
54 \cdot 00\end{array}$ & $\begin{array}{l}52 \cdot 50 \\
50 \cdot 00 \\
42 \cdot 50 \\
40 \cdot 00\end{array}$ & $\begin{array}{r}94.56 \\
138.06 \\
84.00 \\
126.90\end{array}$ & $\begin{array}{r}150.94 \\
130.25 \\
114.75 \\
89.00\end{array}$ \\
\hline E 29 & $\begin{array}{l}1 \\
2 \\
3 \\
4\end{array}$ & $\begin{array}{l}96.00 \\
95.00 \\
95.00 \\
96.50\end{array}$ & $\begin{array}{c}95 \cdot 00 \\
97.00 \\
96.50 \\
95 \cdot 50\end{array}$ & $\begin{array}{r}8 \cdot 50 \\
8 \cdot 70 \\
10 \cdot 70 \\
10 \cdot 60\end{array}$ & $\begin{array}{r}15 \cdot 70 \\
9.50 \\
10.90 \\
10.20\end{array}$ & $\begin{array}{l}50.00 \\
48.00 \\
46.00 \\
56.00\end{array}$ & $\begin{array}{l}48 \cdot 00 \\
46 \cdot 00 \\
50 \cdot 00 \\
41 \cdot 50\end{array}$ & $\begin{array}{l}212 \cdot 50 \\
208 \cdot 50 \\
246 \cdot 10 \\
296 \cdot 80\end{array}$ & $\begin{array}{l}376.80 \\
218.50 \\
272.50 \\
211.65\end{array}$ \\
\hline F 30 & $\begin{array}{l}1 \\
2 \\
3 \\
4\end{array}$ & $\begin{array}{l}141.00 \\
143.50 \\
141.00 \\
101.00\end{array}$ & $\begin{array}{l}152.50 \\
150.50 \\
147.00 \\
108.00\end{array}$ & $\begin{array}{l}4 \cdot 55 \\
5 \cdot 80 \\
6 \cdot 10 \\
4 \cdot 25\end{array}$ & $\begin{array}{l}7 \cdot 55 \\
5.80 \\
7.25 \\
4 \cdot 10\end{array}$ & $\begin{array}{l}84 \cdot 50 \\
82 \cdot 50 \\
82 \cdot 50 \\
70 \cdot 00\end{array}$ & $\begin{array}{l}80 \cdot 00 \\
90 \cdot 00 \\
89 \cdot 00 \\
67 \cdot 00\end{array}$ & $\begin{array}{l}296.80 \\
239.25 \\
251.63 \\
148.75\end{array}$ & $\begin{array}{l}211.65 \\
261.00 \\
322.63 \\
137.35\end{array}$ \\
\hline G 26 & $\begin{array}{l}1 \\
2 \\
3 \\
4\end{array}$ & $\begin{array}{l}127.50 \\
130.50 \\
129.75 \\
129.00\end{array}$ & $\begin{array}{l}147.50 \\
146.00 \\
145.00 \\
142.00\end{array}$ & $\begin{array}{l}2.20 \\
2.80 \\
2.83 \\
2.90\end{array}$ & $\begin{array}{l}2 \cdot 10 \\
3 \cdot 60 \\
3 \cdot 30 \\
3 \cdot 25\end{array}$ & $\begin{array}{l}56.00 \\
73.00 \\
59.00 \\
60.00\end{array}$ & $\begin{array}{l}60 \cdot 00 \\
56 \cdot 00 \\
65 \cdot 00 \\
68 \cdot 00\end{array}$ & $\begin{array}{r}61.60 \\
102.20 \\
83.49 \\
87.00\end{array}$ & $\begin{array}{r}63.00 \\
100.80 \\
107.25 \\
110.50\end{array}$ \\
\hline H 39 & $\begin{array}{l}1 \\
2 \\
3 \\
4\end{array}$ & $\begin{array}{l}126.00 \\
125.00 \\
126.00 \\
120.00\end{array}$ & $\begin{array}{l}114.50 \\
114.00 \\
114.00 \\
110.00\end{array}$ & $\begin{array}{l}4.20 \\
7.05 \\
7.40 \\
4.30\end{array}$ & $\begin{array}{l}3.90 \\
7.50 \\
7.25 \\
6.75\end{array}$ & $\begin{array}{l}57 \cdot 50 \\
62 \cdot 50 \\
66 \cdot 50 \\
49 \cdot 00\end{array}$ & $\begin{array}{l}48 \cdot 50 \\
55 \cdot 00 \\
52 \cdot 00 \\
60 \cdot 50\end{array}$ & $\begin{array}{l}120 \cdot 75 \\
220 \cdot 31 \\
246.05 \\
105 \cdot 35\end{array}$ & $\begin{array}{r}94 \cdot 58 \\
206 \cdot 25 \\
188 \cdot 50 \\
204 \cdot 19\end{array}$ \\
\hline 121 & $\begin{array}{l}1 \\
2 \\
3 \\
4\end{array}$ & $\begin{array}{l}111.00 \\
110.00 \\
108.50 \\
110.00\end{array}$ & $\begin{array}{l}120.00 \\
120.00 \\
118.25 \\
125.50\end{array}$ & $\begin{array}{l}4.00 \\
8.00 \\
7.20 \\
5.95\end{array}$ & $\begin{array}{l}4 \cdot 21 \\
8 \cdot 80 \\
6 \cdot 70 \\
4 \cdot 85\end{array}$ & $\begin{array}{l}27.00 \\
44.00 \\
53.00 \\
53.50\end{array}$ & $\begin{array}{l}58 \cdot 00 \\
54 \cdot 50 \\
53 \cdot 25 \\
52 \cdot 00\end{array}$ & $\begin{array}{r}54.00 \\
176.00 \\
190.80 \\
159 \cdot 16\end{array}$ & $\begin{array}{l}122.09 \\
239 \cdot 80 \\
178 \cdot 39 \\
126 \cdot 10\end{array}$ \\
\hline
\end{tabular}


- free trial (Trial 1) and the subsequent trial without medication (Trial 4). If Trials 1 and 4 proved to be comparable, the respective scores were averaged and the average was treated as the subject's score for $0 \mathrm{mg}$ of myo-inositol. The second analysis for each dependent variable was a $2 \times 2 \times 3$ ANOVA with group, eye and myo-inositol dose as the respective independent variables. In this ANOVA the three levels of the dose factor were $0 \mathrm{mg}$ (Trials 1 and 4), $500 \mathrm{mg}$ (Trial 2) and $1000 \mathrm{mg}$ (Trial 3). Trend analyses of the dose factor were conducted so that a statistically significant effect could be attributed to either its linear or quadrantic component.

(B) CSF inositol determination

We collected CSF from 55 multiple sclerosis patients (mean age 36 years, SD 10 years; 20 males and 35 females) and 21 patients who did not have multiple sclerosis (mean age 37 years, SD 13 years; 10 males and 11 females). Most of the non-multiple sclerosis patients were undergoing myelography for lumbar or cervical disk disease. Other diagnoses included: migraine (1), benign intracranial hypertension (1), hysterical paralysis (2), Guillain-Barré syndrome (1), motor neuron disease (2), cerebral infarction (2), encephalitis (2) Bell's palsy (1) and atypical facial pain (1).

Samples of CSF $(0.5-0.7 \mathrm{ml})$ were diluted to $3.0 \mathrm{ml}$ with distilled water and deproteinised by adding $0.15 \mathrm{ml}$ of trichloroacetic acid $(100 \mathrm{~g} / 100 \mathrm{ml})$. Protein was precipitated by centrifugation and the supernatant was adjusted to $\mathrm{pH} 7-8$ by treatment with Dowex $1-x 8(\mathrm{OH})$ ion-exchange resin. Aliquots of the supernatant solutions were placed in glass vials and dried overnight at $55-60^{\circ} \mathrm{C}$. Dried samples were dissolved in dimethylsulfoxide $(0.1 \mathrm{ml})$ and $0.4 \mathrm{ml}$ of silyating reagent $(7.0 \mathrm{ml}$ pyridine, $2.0 \mathrm{ml}$ hexamethyldisilazene and $1.0 \mathrm{ml}$ trimethylchlorosilane) was added. The reaction was allowed to proceed at $22^{\circ} \mathrm{C}$ for 20 minutes. The byproducts in the reaction mixture were removed by centrifugation. 5-10 $\mu$ l aliquots of reaction mixture were then chromatographed on a glass column using a nitrogen carrier $(45 \mathrm{ml} / \mathrm{min})$ in a Tracor Gas Chromatograph model 560 with a hydrogen flame detector. Temperatures of inlet, detector and outlet were 205,210 and $220^{\circ} \mathrm{C}$ respectively.

Table 2 Control subjects

\begin{tabular}{|c|c|c|c|c|c|c|c|c|c|}
\hline \multirow[t]{2}{*}{ Patient lage (yr) } & \multirow[t]{2}{*}{ Trial } & \multicolumn{2}{|c|}{ Latency (ms) } & \multicolumn{2}{|c|}{ Amplitude $(\mu V)$} & \multicolumn{2}{|c|}{ Duration (ms) } & \multicolumn{2}{|c|}{$\operatorname{Area}(\mu V-m s)$} \\
\hline & & Lefi eye & Right eye & Lefi eye & Right eye & Left eye & Right eye & Lefi eye & Right eye \\
\hline J 47 & $\begin{array}{l}1 \\
2 \\
3 \\
4\end{array}$ & $\begin{array}{l}96.00 \\
94.00 \\
95 \cdot 50 \\
94.00\end{array}$ & $\begin{array}{l}96.00 \\
96.00 \\
95.58 \\
95.00\end{array}$ & $\begin{array}{l}7 \cdot 15 \\
6 \cdot 30 \\
4 \cdot 45 \\
5 \cdot 85\end{array}$ & $\begin{array}{l}6 \cdot 05 \\
5 \cdot 70 \\
4 \cdot 80 \\
5 \cdot 80\end{array}$ & $\begin{array}{l}38.00 \\
39 \cdot 50 \\
51 \cdot 00 \\
56.00\end{array}$ & $\begin{array}{l}45 \cdot 00 \\
44 \cdot 00 \\
40 \cdot 50 \\
56 \cdot 00\end{array}$ & $\begin{array}{l}135.85 \\
124.43 \\
113.48 \\
163.80\end{array}$ & $\begin{array}{r}136 \cdot 13 \\
125 \cdot 40 \\
97 \cdot 20 \\
162 \cdot 40\end{array}$ \\
\hline K 30 & $\begin{array}{l}1 \\
2 \\
3 \\
4\end{array}$ & $\begin{array}{l}95.50 \\
94.50 \\
91.00 \\
92.00\end{array}$ & $\begin{array}{l}93.00 \\
93.00 \\
94.00 \\
93.50\end{array}$ & $\begin{array}{l}17 \cdot 00 \\
16 \cdot 60 \\
13 \cdot 60 \\
13 \cdot 60\end{array}$ & $\begin{array}{l}14 \cdot 40 \\
16 \cdot 35 \\
13 \cdot 90 \\
12 \cdot 70\end{array}$ & $\begin{array}{l}53.00 \\
46.50 \\
50.00 \\
50.00\end{array}$ & $\begin{array}{l}47 \cdot 50 \\
45 \cdot 50 \\
48 \cdot 50 \\
50 \cdot 00\end{array}$ & $\begin{array}{l}450 \cdot 50 \\
385 \cdot 95 \\
340 \cdot 00 \\
340 \cdot 00\end{array}$ & $\begin{array}{l}342.00 \\
371.96 \\
337.08 \\
317.50\end{array}$ \\
\hline L 27 & $\begin{array}{l}1 \\
2 \\
3 \\
4\end{array}$ & $\begin{array}{l}88 \cdot 50 \\
86 \cdot 00 \\
87 \cdot 00 \\
90 \cdot 50\end{array}$ & $\begin{array}{l}95 \cdot 50 \\
83.00 \\
87 \cdot 00 \\
88.00\end{array}$ & $\begin{array}{l}7 \cdot 60 \\
6 \cdot 50 \\
6 \cdot 40 \\
4 \cdot 80\end{array}$ & $\begin{array}{l}4.10 \\
6.65 \\
7.95 \\
6.45\end{array}$ & $\begin{array}{l}42.00 \\
41.00 \\
40.00 \\
43.00\end{array}$ & $\begin{array}{l}48 \cdot 50 \\
39 \cdot 00 \\
41 \cdot 00 \\
45 \cdot 50\end{array}$ & $\begin{array}{l}159 \cdot 60 \\
133 \cdot 25 \\
128 \cdot 00 \\
103 \cdot 20\end{array}$ & $\begin{array}{r}99.43 \\
129.68 \\
162.98 \\
146.74\end{array}$ \\
\hline M 30 & $\begin{array}{l}1 \\
2 \\
3 \\
4\end{array}$ & $\begin{array}{l}87.00 \\
87.00 \\
91.00 \\
90.00\end{array}$ & $\begin{array}{l}88 \cdot 00 \\
90 \cdot 50 \\
92 \cdot 50 \\
90 \cdot 00\end{array}$ & $\begin{array}{l}3 \cdot 20 \\
2 \cdot 25 \\
6 \cdot 10 \\
5 \cdot 40\end{array}$ & $\begin{array}{l}4 \cdot 75 \\
5 \cdot 55 \\
4 \cdot 55 \\
6 \cdot 30\end{array}$ & $\begin{array}{l}53 \cdot 00 \\
41 \cdot 00 \\
42.00 \\
45 \cdot 00\end{array}$ & $\begin{array}{l}53.00 \\
44.00 \\
37.50 \\
46.00\end{array}$ & $\begin{array}{r}84 \cdot 80 \\
46 \cdot 13 \\
128 \cdot 10 \\
121 \cdot 50\end{array}$ & $\begin{array}{r}125 \cdot 89 \\
122 \cdot 10 \\
85 \cdot 31 \\
144 \cdot 90\end{array}$ \\
\hline N 22 & $\begin{array}{l}1 \\
2 \\
3 \\
4\end{array}$ & $\begin{array}{l}94.50 \\
92.00 \\
91.00 \\
91.00\end{array}$ & $\begin{array}{l}94.00 \\
94.00 \\
90.00 \\
93.00\end{array}$ & $\begin{array}{l}5 \cdot 80 \\
3 \cdot 85 \\
4 \cdot 45 \\
4 \cdot 70\end{array}$ & $\begin{array}{l}5 \cdot 70 \\
4 \cdot 00 \\
4 \cdot 35 \\
4 \cdot 85\end{array}$ & $\begin{array}{l}68 \cdot 50 \\
58 \cdot 00 \\
66 \cdot 00 \\
63.00\end{array}$ & $\begin{array}{l}74 \cdot 00 \\
67 \cdot 00 \\
55 \cdot 00 \\
67 \cdot 00\end{array}$ & $\begin{array}{l}198.65 \\
111.65 \\
146.85 \\
148.05\end{array}$ & $\begin{array}{l}210.90 \\
134.00 \\
119.63 \\
162.48\end{array}$ \\
\hline O 25 & $\begin{array}{l}1 \\
2 \\
3 \\
4\end{array}$ & $\begin{array}{l}89 \cdot 50 \\
89 \cdot 50 \\
90 \cdot 50 \\
91 \cdot 00\end{array}$ & $\begin{array}{l}91.00 \\
90.00 \\
90.00 \\
89.00\end{array}$ & $\begin{array}{l}4.35 \\
4.80 \\
4.55 \\
7.00\end{array}$ & $\begin{array}{l}5 \cdot 20 \\
4 \cdot 45 \\
4 \cdot 85 \\
7 \cdot 35\end{array}$ & $\begin{array}{l}62.00 \\
60 \cdot 00 \\
57.00 \\
60 \cdot 00\end{array}$ & $\begin{array}{l}59 \cdot 50 \\
65 \cdot 00 \\
56 \cdot 00 \\
60 \cdot 00\end{array}$ & $\begin{array}{l}134.85 \\
144.00 \\
129 \cdot 68 \\
210.00\end{array}$ & $\begin{array}{l}154.70 \\
144.63 \\
135.80 \\
220.50\end{array}$ \\
\hline P 36 & $\begin{array}{l}1 \\
2 \\
3 \\
4\end{array}$ & $\begin{array}{l}90 \cdot 50 \\
96.00 \\
94 \cdot 00 \\
94.00\end{array}$ & $\begin{array}{l}93.00 \\
95.00 \\
95.50 \\
95.00\end{array}$ & $\begin{array}{l}7 \cdot 35 \\
9 \cdot 20 \\
6 \cdot 85 \\
9 \cdot 40\end{array}$ & $\begin{array}{l}8.45 \\
8.45 \\
9.95 \\
9.20\end{array}$ & $\begin{array}{l}41 \cdot 00 \\
41 \cdot 00 \\
41 \cdot 50 \\
40 \cdot 50\end{array}$ & $\begin{array}{l}44 \cdot 50 \\
46 \cdot 00 \\
43 \cdot 00 \\
50 \cdot 50\end{array}$ & $\begin{array}{l}150 \cdot 68 \\
188 \cdot 60 \\
142 \cdot 14 \\
190 \cdot 35\end{array}$ & $\begin{array}{l}188 \cdot 01 \\
194.35 \\
213.93 \\
232.30\end{array}$ \\
\hline Q 34 & $\begin{array}{l}1 \\
2 \\
3 \\
4\end{array}$ & $\begin{array}{l}93.00 \\
91.00 \\
92.50 \\
91.00\end{array}$ & $\begin{array}{l}91 \cdot 00 \\
90 \cdot 00 \\
94 \cdot 50 \\
91.00\end{array}$ & $\begin{array}{l}2 \cdot 40 \\
3 \cdot 10 \\
3 \cdot 10 \\
3 \cdot 65\end{array}$ & $\begin{array}{l}3.28 \\
2.43 \\
1.95 \\
3.40\end{array}$ & $\begin{array}{l}35 \cdot 00 \\
49 \cdot 50 \\
34 \cdot 50 \\
44 \cdot 00\end{array}$ & $\begin{array}{l}46 \cdot 00 \\
64 \cdot 00 \\
46 \cdot 00 \\
61 \cdot 50\end{array}$ & $\begin{array}{l}42 \cdot 00 \\
76 \cdot 73 \\
53.48 \\
80 \cdot 30\end{array}$ & $\begin{array}{r}75.44 \\
77.76 \\
44.85 \\
104.55\end{array}$ \\
\hline R 27 & $\begin{array}{l}1 \\
2 \\
3 \\
4\end{array}$ & $\begin{array}{l}94 \cdot 50 \\
94 \cdot 00 \\
93 \cdot 50 \\
96.00\end{array}$ & $\begin{array}{l}93.00 \\
95.00 \\
94.00 \\
95.00\end{array}$ & $\begin{array}{l}8.80 \\
9.00 \\
9 \cdot 00 \\
8.20\end{array}$ & $\begin{array}{r}10.40 \\
8.20 \\
9.80 \\
8.50\end{array}$ & $\begin{array}{l}57 \cdot 00 \\
55.00 \\
63.00 \\
59.00\end{array}$ & $\begin{array}{l}61 \cdot 00 \\
57 \cdot 00 \\
54 \cdot 50 \\
55 \cdot 00\end{array}$ & $\begin{array}{l}250 \cdot 80 \\
247 \cdot 50 \\
283 \cdot 50 \\
241 \cdot 90\end{array}$ & $\begin{array}{l}317 \cdot 20 \\
233 \cdot 70 \\
267 \cdot 05 \\
233 \cdot 75\end{array}$ \\
\hline
\end{tabular}


Column temperature was programmed from $152-190^{\circ} \mathrm{C}$. The retention time for the inositol derivative was 28 minutes. Quantitation was obtained by comparing peak areas obtained from samples with peak areas of known concentration of the following polyol mixtures: erithritol, ribitol, L-arabitol, D-sorbitol and myo-inositol. Recovery of polyols was $90-95 \%$ estimated by comparing the recovery of the standard mixture silyated directly with a sample prepared in the same way as CSF samples. Since the isomer myo-inositol comprises almost all of the inositol fraction ${ }^{2}$ the total inositol concentration is equivalent to myo-inositol concentration.

We compared CSF myo-inositol levels of the 55 multiple sclerosis patients with those of the 21 control patients using the $t$ test for two independent means. Paired 1 -tailed $t$ tests were performed on CSF myo-inositol from seven of the nine multiple sclerosis patients from Part $A$ and seven agematched (within 3 years) and sex-matched non-multiple sclerosis patients from Part B.

\section{Results}

(A) Myo-inositol and pattern reversal evoked potentials (see tables 1 and 2 for raw data)

(a)

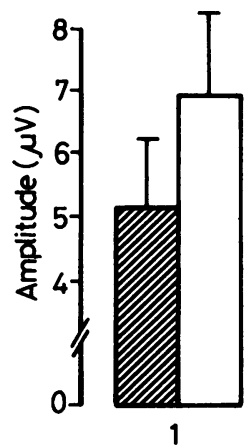

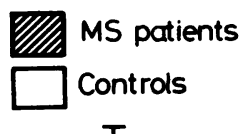

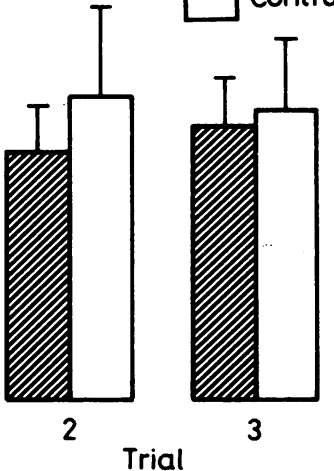

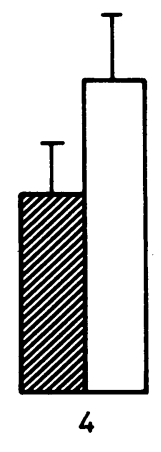
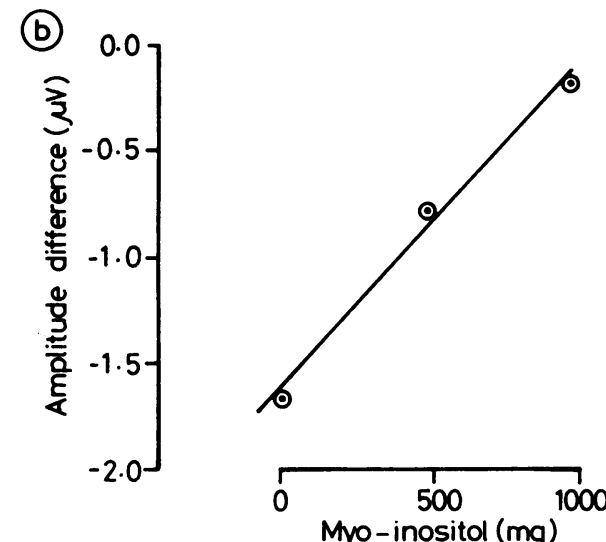

Fig 3 (a) shows mean PREP amplitude for multiple sclerosis patients and controls for the four Trials. Vertical lines represent standard errors of measurement; $(b)$ shows the difference in mean amplitude between multiple sclerosis and control groups for three myo-inositol dosages. Trials 1 and 4 were pooled to give the value for " $O \mathrm{mg}$ myo-inositol". The amplitude difference between multiple sclerosis and controls is linearly related to myo-inositol dosage.

(a) Duration

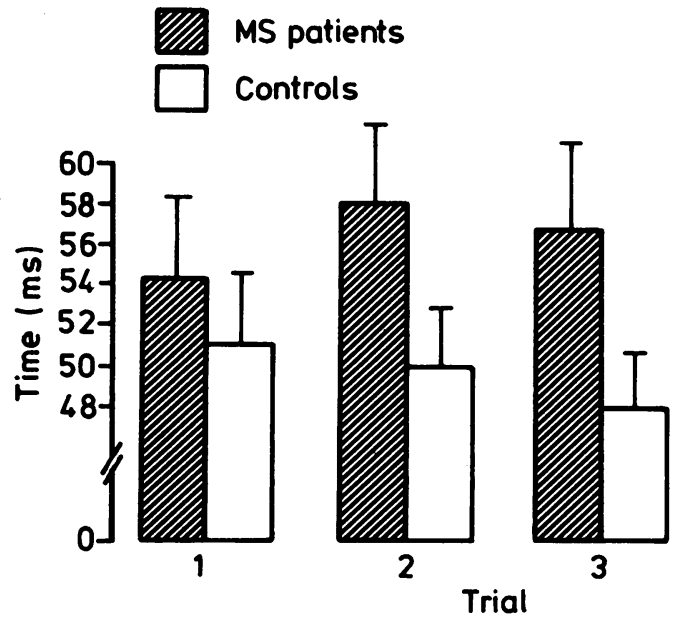

(b)

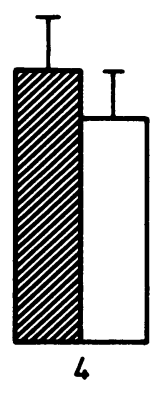

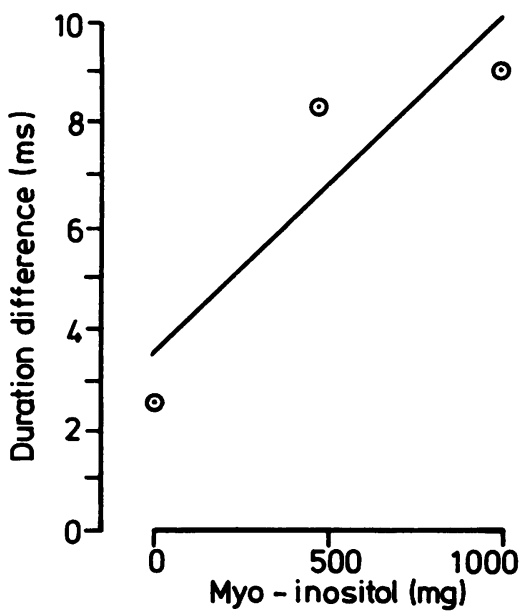

Fig 4 (a) shows mean duration for multiple sclerosis and control groups for the four Trials. Vertical lines represent standard errors of measurement; (b) shows the difference in mean duration between multiple sclerosis and control groups for three myo-inositol dosage regimes. Trials 1 and 4 were pooled to give the value for " 0 mg myo-inositol". The difference between the two groups is linearly related to dose of myo-inositol. 
No change occurred in visual acuity in control subjects or multiple sclerosis patients.

Latency Mean $\mathrm{P}_{2}$ latencies for multiple sclerosis and control groups in the four trials are shown in fig 2. Means for the multiple sclerosis group exceeded those for the control group by 20-26 ms on each trial. An analysis of variance on Trials 1 and 4 was performed to determine whether the two groups differed in the unmedicated state. The design was a $2 \times 2 \times 2$ analysis with Group (multiple sclerosis vs Control), eye and Trial (Trial 1 vs Trial 4) as design factors. The analysis of variance yielded only a significant main effect for group, $F(1,16)=17.52$, p $<0.001$, reflecting the greater mean latency for multiple sclerosis patients. The main effects for Trials and the Group $x$ Trial interaction did not approach statistical significance $(\mathrm{p}>0.25)$.

Since latencies on Trials 1 and 4 were equivalent, these data were averaged to provide an estimate of latency in the unmedicated state. An analysis of variance was then performed to evaluate the effect of 0
(Trials 1 and 4 pooled), 500 (Trial 2) and 1000 (Trial 3) mg of myo-inositol on $\mathrm{P}_{2}$ latency. The only significant effect was the main effect for group, $F(1,16)=16 \cdot 22, \mathrm{p}=0.011$, which again reflects the greater latency in the multiple sclerosis group. There was neither a significant dose effect, $F<1$, nor a significant Group $\times$ Dose interaction, $F(2,32)$, $p>0 \cdot 35$. Thus the latencies are not significantly altered by 500 or $1000 \mathrm{mg}$ doses of myo-inositol.

Amplitude Mean $\mathrm{P}_{2}$ amplitudes for the multiple sclerosis and control groups on each of the four Trials are shown in fig 3(a). Amplitude data were analysed in the same manner as the latency data. Preliminary analysis from the medication-free conditions (Trials 1 and 4) yielded no significant difference between groups $(p>0 \cdot 20)$. In addition there was no significant Trial effect or Group $\times$ Trial interaction $(F<1)$.

An analysis of variance was performed to assess the effects of 0 (Trial 1 and 4 pooled), 500 (Trial 2) and 1000 (Trial 3) mg of myo-inositol. Although the main
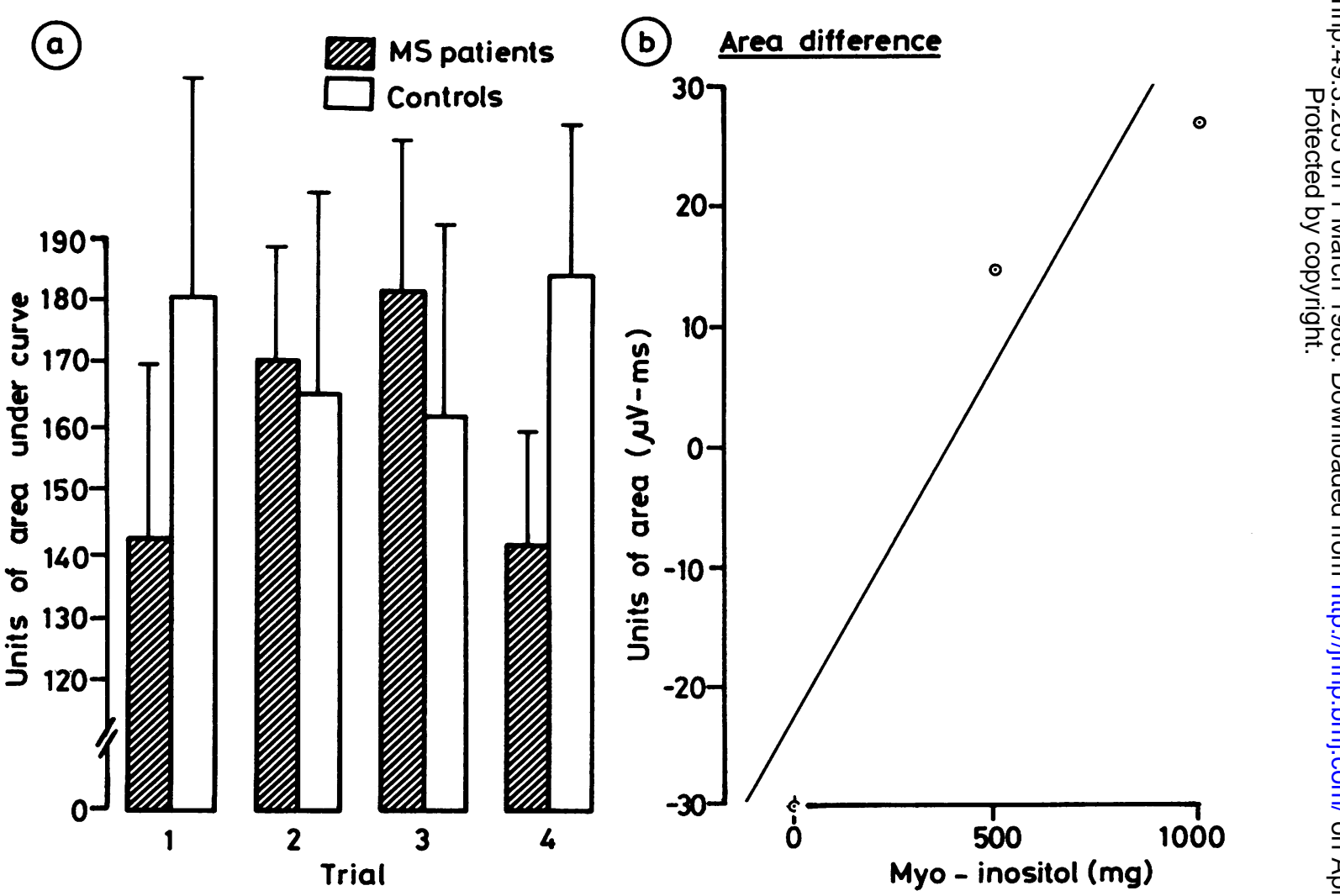

Fig 5 (a) shows mean area of $N_{1} P_{1} N_{2}$ complex in multiple sclerosis and control groups for the four Trials. Vertical lines represent standard errors of measurement; $(b)$ shows the difference in mean area between multiple sclerosis and control groups for the three doses of myo-inositol. Trials 1 and 4 were pooled to give the value for " $0 \mathrm{mg}$ myo-inositol". The difference in area is linearly related to myo-inositol dosage. 
effects for group $F<1$, and for dose $F(2,32)-1.03$ $p>0.35$ were both nonsignificant, there was a significant group $\times$ dose interaction, $F(2,32)=3 \cdot 30$, $\mathrm{p}=0.05$. Moreover trend analyses showed that the interaction is attributable to the linear component, $F(1,16)=7.90, p=0.01$. The amplitude in the multiple sclerosis group increased compared with controls, the differential increase being related to dose in a linear manner [see fig 3(b)].

Duration The $\mathrm{N}_{2}-\mathrm{N}_{1}$ interval in ms for each group on each of the four Trials is shown in fig 4(a). As was the case with amplitude data, a preliminary analysis of duration from Trials 1 and 4 failed to show any differences. After Trials 1 and 4 were pooled, an analysis of variance was performed to ascertain the effects of myo-inositol dose. Neither the main effect for groups, $F(1,16)=2 \cdot 13, \mathrm{p}>0 \cdot 15$, nor the main effect for dose, $F<1$ reached an acceptable level of statistical significance. Again there was a significant Group $\times$ Trials interaction, $F(2,32)=4.35, \mathrm{p}<0.025$, which can be attributed to the linear component, $F(1,16)=8 \cdot 55, \mathrm{p}=0 \cdot 01$. Myo-inositol enhanced the difference in duration by increasing the mean duration in the multiple sclerosis group and by decreasing it in the control group. The difference in duration between the two groups varied as a linear function of dose from 0-1000 mg. See fig 4(b).

Area under the curve The mean for multiple sclerosis and control groups and for each of the four trials is shown in fig 5(a). Although the mean area for the control group is greater than for the multiple sclerosis patients by about $40 \mu \mathrm{V}$-ms units in the medicationfree Trials ( 1 and 4$)$, the disparity in the two medication conditions is in the opposite direction; multiple sclerosis patients show the greater mean area by 5 units in the $500 \mathrm{mg}$ Trial 2 and by 26 units in the $1000 \mathrm{mg}$ Trial 3.

A preliminary analysis of variance on Trials 1 and 4 showed no significant Group $\times$ Trial interaction or effect for group or Trial. With Trials 1 and 4 pooled, on analysis there was a significant Group $\times$ Dose interaction, $F(2,32)=7.65, \mathrm{p}<0.005$, which reflects an increase in area for the multiple sclerosis group and a decrease in area for the control group. The group $x$ dose interaction is largely attributable to the linear component, $F(1,16)=11.51, p<0.005$. The medication-related relative increase in area for the multiple sclerosis group varied linearly with dose (fig 5b).

\section{(B) CSF inositol determination}

The mean levels of myo-inositol in the CSF of 55 multiple sclerosis and 21 control patients were similar (175 and $188 \mu \mathrm{mol} / 1$ respectively). Variation within each group was marked (standard deviations for multiple sclerosis and control groups were 96 and
$126 \mu \mathrm{mol} / 1$ respectively). A paired 1-tailed $t$ test using seven of the nine multiple sclerosis patients who were in Part A of the study, with seven age-sex matched control non-multiple sclerosis patients did not show a significant difference between the 2 groups ( $p>0 \cdot 19)$.

\section{Discussion}

Based on its topography ${ }^{13}$ the $P_{2}$ wave is likely generated in the visual cortex by local synaptic activity in response to visual stimulation. The $P_{2}$ latency is often delayed in multiple sclerosis patients probably because of conduction slowing due to demyelination. ${ }^{14}$ We also found a significant delay in mean $P_{2}$ latency in multiple sclerosis patients compared with control subjects. Myo-inositol administration was not associated with any alteration of the latency in either group, indicating conduction velocity was not affected.

Our main finding is that multiple sclerosis patients and control subjects differ significantly in the alteration of mean values of $P_{2}$ amplitude, duration and area associated with myo-inositol administration. Furthermore the differences between the two groups are dose-dependent in a linear manner. It appears to us these findings reflect a differential response to myoinositol on either conduction or on synaptic activity.

Although conduction velocity does not appear to be increased, reversal of conduction block in some demyelinated axons in the visual pathway could produce an enhanced $P_{2}$ response. In view of the acute reversal of its effect, it seems unlikely the administered myo-inositol altered the physical structure of the axon to correct the transmembrane capacitance and resistance ${ }^{15}$ or impedence mismatch ${ }^{1617}$ causing the conduction block. Hawthorne and $\mathrm{Kai}^{1}$ proposed phosphoinositides play a role in ion channel gating. Although this has never been proven, a mechanism involving turning off sodium influx ${ }^{18}$ or blocking potassium channel activation ${ }^{15}$ may overcome conduction block.

Proposing a synaptic effect of myo-inositol raises the controversial topic of altered synaptic activity in multiple sclerosis. ${ }^{19-26}$ It is still unsettled as to whether there is a "synaptic blocking factor" in multiple sclerosis, although there is some evidence for altered synaptic function produced by multiple sclerosis sera. ${ }^{19-222425}$ Eisen et $a l^{26}$ also found altered neuromuscular transmission in multiple sclerosis.

Recent biochemical studies have revealed a prominent role for inositol phospholipids in the function of numerous types of receptors. ${ }^{357}$ When specific postsynaptic receptors are activated, phospholipase C hydrolyses phosphoinositides. One product, inositol triphosphate, is thought to function as a "second 
messenger" in those systems which do not use cyclic adenosine monophosphate (cyclic AMP).$^{568}$ Inositol triphosphate increases intracellular ionised calcium concentration by causing its release from storage sites and probably by opening membrane channels for calcium. Calcium then activates various cellular enzyme systems. Thus there is an "amplifying effect" of inositol phospholipids on the function of certain neurotransmitters. ${ }^{57}$ The administration of extra inositol could augment this second messenger function. Such an effect might be more pronounced if the system is malfunctioning from partial synaptic blockade. It is also of interest that phosphatidylinositol phosphodiesterase which cleaves phosphatidylinositol is inhibited by blood plasma, serum and blood lipoproteins. ${ }^{27}$ Such substances could have access to receptor sites if the blood-brain barrier were not intact.

We found no significant differences in CSF myoinositol concentrations in multiple sclerosis and control patients. Our values are similar to those reported by Servo $e t$ al $^{28}$ using a gas-liquid chromatographic assay and Garcia-Bunuel et $a^{29}$ using an enzymatic assay. Neither study had more than 6 multiple sclerosis patients. Two with "acute multiple sclerosis" had slightly elevated CSF myo-inositol levels, ${ }^{29}$ the others did not differ from controls. It is possible the inositol was released into the CSF by myelin destruction in the acute cases. It is uncertain whether CSF levels reflect tissue levels of myo-inositol, but we have no evidence for deficiency of myo-inositol in multiple sclerosis.

Administered myo-inositol appears to have a differential pharmacological effect on pattern reversal evoked potential responses in multiple sclerosis patients and healthy controls. It is unclear whether this has any therapeutic implications. Although we noted no convincing clinical improvements during or following our study, this could be better assessed in a clinical study.

This study was supported by grants from the Multiple Sclerosis Society of Canada and the Saskatchewan Health Research Fund.

The authors thank Mr Terry Hogan and Mrs Asha Pawagi for technical assistance, Drs TE Feasby, G Ebers, M Rathbone, I Mendelson and WT Blume for their helpful suggestions and criticism and Mrs Andrea Byers for typing the manuscript.

\section{References}

${ }^{1}$ Hawthorne JN, Kai M. Metabolism of phosphionositides. In: Lajtha A, ed. Handbook of Neurochemistry. New York: Plenum, Vol 3, 1970:491-507.
${ }^{2}$ Simmons DA, Winegrad AI, Martin DB. Significance of tissue myo-inositol concentrations in metabolic regulation in nerve. Science 1982;217:848-51.

${ }^{3}$ Larabee MG, Leicht WS. Metabolism of phosphatidylinositol and other lipids in active neurons of sympathetic ganglia and other peripheral nervous tissue. The site of the inositide effect. $J$ Neurochem 1965;12:1-13.

${ }^{4}$ Hawthorne JN. Is phosphatidylinositol now out of the calcium gate? Nature 1982;295:281-2.

${ }^{5}$ Downes CP. Receptor-stimulated inositol phospholipid metabolism in the central nervous system. Cell Calcium 1982;3:413-28.

${ }^{6}$ Berridge MJ, Dawson RMS, Downes CP, Heslop JP, Irvine RF. Changes in the levels of inositol phosphates after agonist-dependent hydrolysis of membrane phosphoinositides. Biochem J 1983;212:473-82.

${ }^{7}$ Downes CP. Inositol phospholipids and neurotransmitter-receptor signalling mechanisms. Trends Neurosci 1983;6:313-6.

${ }^{8}$ Marx JL. A new view of receptor action. Science 1984;224:271-4.

${ }^{9}$ Nishizuka Y. The role of protein kinase $\mathrm{C}$ in cell surface signal transduction and tumor promotion. Nature 1984;308:693-8.

${ }^{10}$ Holm V. Inositol in multiple sclerosis. Arch Neurol 1978;35:478.

${ }^{11}$ Winegrad AI, Greene DA. Diabetic polyneuropathy: the importance of insulin deficiency, hyperglycemia and alterations in myo-inositol in its pathogenesis. $N$ Engl $J$ Med 1976;295:1416-21

${ }^{12}$ Schumacher GA, Beebe G, Kibler RF, et al. Problems of experimental trials of therapy in multiple sclerosis: report by the panel on the evaluation of experimental trials of therapy in multiple sclerosis. Ann NY Acad Sci 1965;122:552-68.

${ }^{13}$ Halliday AM, Barrett G, Halliday E, Michael WF. The topography of the pattern-evoked potential. In: Desmedt JE, ed. Visual Evoked Potentials in Man: New Developments. Oxford: Clarendon Press, 1977:121-33.

${ }^{14}$ Halliday AM, McDonald WI, Mushin J. Visual evoked responses in the diagnosis of multiple sclerosis. $\mathrm{Br} \mathrm{Med}$ $J$ 1973;4:661-4.

${ }^{15}$ Bostock H, Sears TA. The internodal axon membrane: Electrical excitability and continuous conduction in segmental demyelination. J Physiol 1978;200:273-301.

${ }^{16}$ Waxman SG. Prerequisites for conduction in demyelinated fibers. Neurology (Minneap) 1978;28:27-33.

${ }^{17}$ Waxman SG, Brill MH. Conduction through demyelinated plaques in multiple sclerosis: computer simulations of facilitation by short internodes. $J$ Neurol Neurosurg Psychiatry 1978;41:408-16.

${ }^{18}$ Bostock H, Sherratt RM, Sears TA. Overcoming conduction failure in demyelinated nerve fibres by prolonging the action potentials. Nature 1978;274:385-7.

${ }^{19}$ Bornstein MB, Crain SM. Functional studies of cultured brain tissues as related to demyelinative disorders. Science 1975;148:1242-4.

${ }^{20}$ Cerf JA, Carels G. Multiple sclerosis: serum factor producing reversible alterations in bioelectric responses. Science 1966;152:1066-8.

${ }^{21}$ Davis FA, Schauf CL. Neural blocking activity of mul- 
tiple sclerosis and EAE sera. Neurology (Minneap) 1976;26 (suppl):43-4.

${ }^{22}$ Schauf CL, Davis FA, Sack DA, Reed BJ, Kesler RL. Neuroelectric blocking factors in human and animal sera evaluated using the isolated frog spinal cord. $J$ Neurol Neurosurg Psychiatry 1976;39:680-5.

${ }^{23}$ Seil FJ, Leiman AL, Kelly JM. Neuroelectric blocking factors in multiple sclerosis and EAE sera. Arch Neurol 1976;33:418-22.

${ }^{24}$ Crain SM, Bornstein MB, Lennon VA. Depression of complex bioelectric discharges in cultured cerebral tissue cultures by thermolabile dependent serum factors. Exp Neurol 1975;49:330-5.

${ }^{25}$ Lumsden CE, Howard L, Aparicio SR, Bradbury $M$. Anti-synaptic antibody in allergic encephalomyelitis II. The synapse-blocking effects in tissue culture of demye- linating sera from experimental allergic encephalomyelitis. Brain Res 1975;93:283-99.

${ }^{26}$ Eisen A, Yufe R, Trop D, Campbell D. Reduced neuromuscular transmission safety factor in multiple sclerosis. Neurology (Minneap) 1978;28:598-602.

${ }^{27}$ Dawson RMC, Heminton N, Irvine RF. The inhibition and activation of $\mathrm{CA} 2+$-dependent phosphatidylinositol phosphodiesterase by phospholipids and blood plasma. Eur J Biochem 1980;112:33-8.

${ }^{28}$ Servo C, Palo J, Pikkanen E. Polyols in the cerebrospinal fluid and plasma of neurological diabetic and uremic patients. Acta Neurol Scand 1977;56:111-6.

${ }^{29}$ Garcia-Bunuel L, Garcia-Bunuel VM. Cerebrospinal fluid levels of free myoinositol in some neurological disorders. Neurology (Minneap) 1965;15:348-50. 